\title{
Model Kearifan Lokal dalam Konteks Pembangunan Pariwisata
}

\author{
Azhar $^{1)}$, Agussabti $^{2)}$ dan Indra ${ }^{3)}$ \\ ${ }^{1}$ Fakultas Pertanian, Universitas Syiah Kuala \\ email: azhargani@unsyiah.ac.id \\ ${ }^{2}$ Fakultas Pertanian, Universitas Syiah Kuala \\ email: agussabti@unsyiah.ac.id \\ ${ }^{3}$ Fakultas Pertanian, Universitas Syiah Kuala \\ email: indrazainun@unsyiah.ac.id
}

\begin{abstract}
Local wisdom is one of the cultural values that are still manifest in the order of life of the people in Indonesia. It is a valuable concept so that it can be used as a guide to behavior in a society. This research was conducted with the aim of (1) analyzing the forms of local wisdom contained in the community and their impact on tourism development; (2) finding models or innovations in forms of local wisdom in an effort to realize sustainable development in general and tourism development in particular. This study was conducted at Gampong Aneuk Laot and Gampong Iboih by involving community elements, namely the Village Head, Tuha Peuet, Religious Leaders, cultural figures and tourism actors. Overall, it can be concluded that the value of local wisdom, especially environmental aspects, is a driving factor for proper economic and sociocultural aspects to be used as a model of local wisdom that can guarantee the sustainability of tourism development.
\end{abstract}

Keywords: Local wisdom, tourism development, religion and culture

\section{Pendahuluan}

Isu mengenai kearifan lokal masih hangat didiskusikan dalam konteks budaya masyarakat. Salah satu isu adalah berkaitan dengan pembangunan pariwisata dalam konteks kearifan lokal. Dalam perspektif agama, isu mengenai pembangunan pariwisata masih menarik untuk dikaji mengingat masih terdapat negara yang penduduknya beragama Islam fokus kepada sektor pariwisata seperti Indonesia dan Malaysia. Bagaimanapun, terdapat beberapa negara Islam lain seperti Arab Saudi, Iran dan Brunei Darussalam tidak menggalakkan sektor pariwisata. Pada pandangan negara-negara ini, sektor pariwisata menghadapi belbagai masalah sosial budaya dan melanggar syariat Islam (Mathieson \& Wall, 1982; Din, 1989; Aziz, 1995; Baum \& Conlin, 1997; Zamani-Farahani \& Henderson, 2010). Secara spesifik, antara masalah yang bertentangan dengan syariat Islam dan lazim berlaku seperti pihak penginapan membolehkan pasangan bukan muhrim menginap dalam satu kamar, perjudian, minuman keras, dan makanan tidak halal (Joseph \& Kavoori,2001). Pada satu pihak, turis asing terutama dari kalangan bukan Islam 
mempunyai kebiasaan mengamalkan perkara-perkara yang malah bertentangan dengan adat budaya dan nilai-nilai Islam. Pada pihak lain, penduduk lokal harus menjaga dan mempertahankan supaya nilai-nilai budaya dan agama tidak berpengaruh negatif jika sektor pariwisata dikembangkan (Kadir Din, 1989: Brown, 1996). Situasi seperti digambarkan di atas sangat delematis bagi penduduk lokal jika mereka ingin berpartisipasi dalam kegiatan di sektor pariwisata.

Sebagaimana diketahui bahwa Provinsi Aceh merupakan satu-satunya provinsi yang melaksanakan Syariat Islam (Islamic law) di Indonesia setelah diberlakukan Undang-Undang Nomor 44 tahun 1999 dan Undang-Undang Nomor 18 tahun 2001. Syariat Islam secara sah dan resmi telah dideklarasi oleh Gubernur Provinsi Nanggroe Aceh Darussalam pada 15 Maret tahun 2002 atau bertepatan dengan 1 Muharram 1423 Hijriah. Pelaksanaan undang-undang Syariat Islam itu turut memberikan berbagai dampak terhadap kehidupan masyarakat tidak terkecuali sektor pariwisata. Sebagai ilustrasi penduduk melakukan protes seperti melakukan pengrusakan dan pembakaran gerai makanan dan minuman di pinggir pantai di luar kota Banda Aceh (The Globe Journal, 2012). Kasus lain juga terjadi ketika penduduk beberapa desa berdekatan destinasi wisata di pusat kota Banda Aceh menutup akses ke destinasi karena beranggapan telah melanggar nilai budaya dan ajaran agama Islam (The Atjeh Post, 2012). Protes tidak hanya datang daripada penduduk. Pihak ulama juga turut menentang ketika investor luar hendak mendirikan hotel Best Western bertaraf internasional berdekatan Masjid Raya Baiturrahman di pusat kota Banda Aceh (The Globe Journal, 2011).

Misri (2010) dalam penulisannya menilai bahwa masih terdapat pandangan negatif terhadap sektor pariwisata di kalangan umat Islam di Aceh, khususnya yang berkait dengan budaya luar yang bertentangan dengan syariat Islam. Beliau memberi pandangan bahwa sebagai Muslim yang taat dalam menjalankan syariat Islam, masyarakat Aceh selalu mengawal daerahnya daripada aktivitas-aktivitas yang bertentangan dengan syariat Islam. Sementara, Totok Yulianto (2008), salah satu pengusaha pengangkutan dalam satu wawancara dengan media nasional menjelaskan bahwa kemunduran industri pariwisata di Provinsi Aceh merupakan dampak dari pelaksanaan syariat Islam.

Dari fenomena dan kenyataan yang telah dipaparkan di atas, diketahui bahwa nilai agama dan budaya memiliki peranan dalam kehidupan masyarakat. Permasalahan yang ingin dikaji dan telusuri melalui penelitian ini adalah apakah terdapat nilainilai budaya (kearifan lokal) terutama yang berkaitan dengan pengembangan pariwisata? Jika ada nilai-nilai apa saja yang dapat dikategorikan sebagai penerima dan penolak dalam industri pariwisata? Oleh karena itu, penelitian ini akan melibatkan masyarakat yang dikelompokkan kepada dua kelompok yaitu Tuha Peuet dan Ureung Awam. Kedua-dua kelompok ini tinggal di Kota Sabang. Eksistensi kelompok ini dalam masyarakat Aceh merupakan salah satu bentuk kearifan lokal yang telah tumbuh dan berakar semenjak dahulu.

\section{Kajian Pustaka}

Terdapat banyak definisi dan batasan mengenai kearifan lokal. Nurma Ali Ridwan (2007) menyebutkan bahwa kearifan lokal dapat dipahami sebagai usaha manusia dengan menggunakan akal budi (kognisi) untuk bertindak dan bersikap terhadap 
sesuatu, objek atau peristiwa yang terjadi dalam ruang tertentu. Selain itu kearifan lokal secara etimologi dapat bermakna kemampuan seseorang dengan menggunakan akal pikirannya untuk menyikapi sesuatu kejadian, objek atau situasi. Istilah lokal menunjukkan ruang interaksi dimana peristiwa atau situasi terjadi. Kearifan lokal merupakan perilaku positif manusia dalam berhubungan dengan alam dan lingkungan sekitarnya yang dapat bersumber dari nilai agama, adat istiadat, serta budaya setempat yang terbangun secara alamiah dalam suatu komunitas masyarakat untuk beradaptasi dengan lingkungan sekitarnya.

Secara umum, kearifan lokal muncul melalui proses internalisasi yang panjang dan berlangsung turun-temurun sebagai akibat interaksi antara manusia dengan lingkungannya. Proses evolusi yang panjang ini bermuara pada munculnya sistem nilai yang terkristalisasi dalam bentuk hukum adat, kepercayaan dan budaya setempat.

Nilai budaya adalah satu bahagian daripada kebudayaan masyarakat tertentu dimana ia merupakan suatu konsepsi abstrak yang dianggap baik dan amat bernilai tinggi sehingga dapat dijadikan sebagai asas atau pegangan tingkah laku dalam suatu masyarakat (Muhammad Yunus Melalatoa, 2005). Oleh karena itu, setiap bangsa di dunia ini memiliki budaya yang diwarisi secara turun temurun tidak terkecuali masyarakat Aceh. Nilai-nilai budaya sesebuah bangsa sedikit sebanyak membawa pengaruh kepada sistem kepimpinan.

Dalam konteks masyarakat Aceh, pemahaman nilai-nilai budaya dalam sistem kepimpinan dapat dilihat daripada pelbagai ungkapan peribahasa (Lunde \& Wintle, 1984). Ungkapan peribahasa itu seterusnya dapat dijadikan garis panduan bagi menilai tingkah laku seharian semasa berinteraksi antara sesama anggota masyarakat. James Danandjaja (1984) menjelaskan sebagai bahagian daripada cerita lisan atau dongeng rakyat (folklore), peribahasa memang berfungsi menjadi pengukuh pranata dan institusi kebudayaan, alat kawalan, pengaturan norma-norma masyarakat dan juga sebagai alat komunikasi dan kawalan sosial. Ringkasnya, kandungan peribahasa berkenaan dimaksudkan untuk memberikan arahan, contoh ikutan, harapan serta nasihat sehingga dapat dijadikan sebagai bahan pembelajaran berharga dalam menjalani kehidupan seharian masyarakat.

Selain itu, ungkapan peribahasa dapat digunakan untuk menunjukkan jati diri atau watak daripada sesebuah masyarakat. Tidak mengherankan jika jati diri itu memberi rasa bangga bagi masyarakat. Misalnya, bagi masyarakat Aceh dikenal istilah Hadis Maja atau Narit Maja. MenurutZaini Ali (2009), Narit Maja adalah tutur perkataan orang-orang tua zaman dahulu yang dapat dijadikan nasihat, panduan, petua, serta ajaran dan umumnya ia (Narit Maja) tersebut berkait rapat dengan agama, adat istiadat (resam) dan kehidupan masyarakat. Masih menurutZaini Ali (2009), tahap kebenaran Narit Maja berada pada peringkat ketiga selepas Wahyu Allah SWT dan Hadis Rasullullah SAW masing-masing pada peringkat pertama dan kedua. Oleh karena kebenaran Hadis Maja berada di bawah Hadis Rasullullah, maka orang-orang Aceh juga menyebutnya dengan istilah Hadis Maja. Bagi orang Aceh, terdapat ungkapan Hadis Maja atau Narit Maja yang menggambarkan melayani tamu seperti berikut ini.

"Peumulia Jamee Adat Geutanyoe" 
(Memuliakan tetamu adalah adat budaya kita).

Nilai-nilai kearifan lokal dalam konteks budaya Aceh tersebut adalah bersesuaian dengan al-Quran dan ajaran Islam, dimana umat Islam tidak hanya digalakkan melakukan perjalanan tetapi juga berbuat baik dengan tamu mereka (ZamaniFarahani \& Henderson, 2010). Hal tersebut selaras dengan Hadis Nabi yang bermaksud.

"Siapa yang beriman kepada Allah dan hari akhirat hendaklah dia memuliakan tamu yang datang kepadanya, dan hendaklah dia menghubungkan silaturahim dan hendaklah dia berkata yang baik atau diam "

(Hadis Riwayat Bukhari). Muhammad ibn ismail Al Bukhari, shahih al-bukhari, (Beirut: Dar ibn katsir, 1987), juz 5, hal. 2273

Selain itu, dalam konteks kepimpinan masyarakat Aceh menempatkan kedudukan pemimpin sebagai contoh teladan dalam kehidupan sehari-hari. Misalnya, dalam salah satu Hadis Maja atau Narit Maja disebutkan.

"Nyankeuh raja nyang seureulo

Aneuk nanggroe that geuaja"

(Itulah raja yang amat utama, senantiasa mengajarkan rakyat)

Sementara, apabila pemimpin tidak berlaku adil kepada pengikutnya (masyarakat), maka mereka akan membuat perlawanan sebagaimana dapat dilihat pada Hadis Maja atau Narit Maja ini.

"Raja ade geuseumah

Raja laklem geusanggah"

(Raja adil disembah, raja zalim dicegah)

Prinsip-prinsip hidup warisan orang-orang zaman dahulu itu, sampai hari ini masih dipegang kokoh oleh masyarakat di Aceh. Selain daripada prinsip-prinsip hidup dalam kepimpinan yang berteraskan kepada nilai-nilai budaya itu, sistem kepimpinan masyarakat Aceh juga amat dipengaruhi oleh nilai-nilai ajaran Islam. Oleh karena itu, dalam konteks pembangunan pariwisata, penelitian ini menjadi penting dimana masyarakat sebagai satu satu pihak berkepentingan turut memberikan kontribusi melalui bentuk-bentuk kearifan lokal yang telah menyatu dalam kehidupan masyarakat.

\section{Metode}

Pendekatan kualitatif telah dipilih untuk digunakan dalam penelitian ini. Dalam konteks kajian ini, justifikasi penggunaan metode kualitatif mengacu kepada Deery, Jago, dan Fredline (2012). Menurut Deery et.al (2012), kelemahan pendekatan kuantitatif apabila digunakan untuk meneliti pandangan masyarakat terletak pada kesimpulan penelitian yang diperoleh tidak dapat memberi gambaran seutuhnya dibandingkan pendekatan kualitatif. Selain itu, para peneliti tersebut menekankan 
bahwa pendekatan kuantitatif tidak mampu menerangkan alasan yang menyebabkan dan mengapa sesuatu kejadian atau gejala yang terjadi dalam masyarakat. Kelebihan lain penggunaan pendekatan kualitatif terletak pada jumlah sampel kecil tetapi menghendaki informasi lebih banyak. Ia berbeda dengan pendekatan kuantitatif yang memerlukan jumlah sampel lebih banyak tetapi informasi yang ingin diperoleh terbatas (Veal, 1997). Oleh karena itu, peneliti menggunakan teknik wawancara mendalam untuk mengumpulkan data.

Pendekatan In-depth interview digunakan untuk mendapatkan pemahaman yang lebih terperinci mengenai fenomena sosial yang sedang diteliti. Hernandez, Cohen, dan Garcia (1996) menjelaskan untuk mendapatkan data mengenai pemikiran dan sikap responden adalah lebih baik menggunakan wawancara mendalam dibandingkan dengan teknik sensus. Pada teknik sensus pertanyaan-pertanyaan yang dibentuk adalah berstruktur dan tertutup sehingga data yang diperoleh juga terbatas. Sedangkan informasi yang didapat melalui wawancara mendalam lebih banyak dan terperinci mengingat peneliti bebas menjaring berbagai isu dan fenomena secara terbuka dengan responden (Veal,1997).

Penelitian ini dilakukan di Pulau Weh, Sabang Propinsi Aceh Indonesia. Studi kasus digunakan sebagai pendekatan dalam penelitian ini. Menurut Rasid Mail dan Raman Noordin (2012:187) studi kasus merupakan satu pendekatan kajian yang fokus kepada jumlah kasus yang terbatas sehingga analisis mendalam dan menyeluruh dapat lakukan terhadap kasus tersebut. Studi kasus juga merupakan proses penyiasatan terperinci dan menyeluruh suatu fenomena dengan memperhitungkan kedudukan keseluruhan konteks dan proses fenomena tersebut. Dalam konteks studi kasus, masalah ukuran sampel adalah berbeda dibandingkan dengan survei. Dalam survei, besarnya sampel menjadi satu hal penting dan harus mewakili populasi untuk menghasilkan hasil penelitian yang menyeluruh. Sementara itu, pendekatan studi kasus lebih menekankan kepada informasi atau data yang menyeluruh dan mendalam dan bukannya pada jumlah sampel yang besar semata-mata. Makna yang mendalam dan menyeluruh agak mustahil diperoleh jika ukuran sampel yang diteliti adalah besar (Rasid Mail \& Raman Noordin, 2012: 187).

Berdasarkan kepada penjelasan di atas, beberapa kecamatan yang terdapat di Kota Sabang dipilih sebagai lokasi penelitian. Hal tersebut mengingat tujuan penelitian ini yaitu untuk mengetahui bentuk-bentuk kearifan lokal dalam konteks pembangunan pariwisata. Secara detail, responden akan dikelompokkan kepada dua yaitu responden yang mempunyai kedudukan dalam struktur pemerintah desa dan mereka yang berada diluar struktur pemerintahan. Keunikan sistem pemerintahan di Aceh dimana terdapat kepemimpinan informal. Sistem kepemimpinan itu merupakan kearifan lokal masyarakat Aceh yang masih berlaku sampai hari ini. Seterusnya, pengambilan sampel dilakukan secara sengaja (Purposive Sampling) telah dipilih untuk digunakan dalam penelitian ini. Kawasan kajian dipilih dengan pertimbangan salah satu destinasi pariwisata Islami oleh Pemerintah Indonesia. Persampelan secara sengaja sering digunakan oleh peneliti dengan berbagai pertimbangan (Judgemental Sampling) antara lain keunikan maupun fenomena terkini yang berlaku dan berdasarkan kepada keperluan peneliti (Jennings, 2001). Teknik ini juga dapat digunakan jika kerangka data yang 
sebenarnya tidak diperoleh (Sekaran, 2003). Oleh karena itu, pertimbangan subjektif peneliti sangat dominan wujud dalam pemilihan responden.

Berdasarkan kepada kenyataan di atas, peneliti memilih responden yang tinggal di kecamatan-kecamatan dimana terdapat destinasi pariwisata. Banyaknya destinasi pariwisata di kawasan ini merupakan salah satu alasan peneliti untuk melaksanakan penelitian. Pengambilan sampel berstrata (Stratified Sampling Method) dan persampelan bola salju (Snowball Sampling) digunakan dalam kajian ini. Menurut Azizi Yahaya, Shahrin Hashim, Jamaludin Ramli, Yusof Boon, dan Abdul R. Hamdan (2006:75) penggunaan persampelan strata menambah peluang bagi peneliti untuk mendapatkan data yang mewakili populasi dan dengan itu menambahkan ketepatan keputusan. Berdasarkan kepada persampelan berstrata, peneliti menggolongkan masyarakat yang berasal dari kelompok Tuha Peuet (pemimpin informal) dan penduduk yang berasal dari kelompok Ureung Awam (masyarakat biasa). Adapun desa penelitian adalah Aneuk Laot dan Iboih. Masingmasing responden dari desa-desa dalam kecamatan terpilih kemudian diwawancara dengan menggunakan teknik diskusi kelompok terpimpin (FGD).

Tiga teknik utama yang biasa digunakan dalam penelitian kualitatif, yaitu (1) wawancara, (2) pengamatan, dan (3) bukti dokumen (Spradley, 1980; Merriam, 1988; Bogdan \& Biklen, 1998) digunakan sepanjang penelitian ini dilaksanakan sebagaimana dikutip dalam (Marohaini Yusoff, 2001: 88). Wawancara biasanya digunakan sebagai teknik pengumpulan data berdasarkan paradigma naturalistik (Halcomb dan Davidson, 2006) dan ia telah menjadi kasus untuk waktu yang agak lama dalam bidang sosial (Fasick, 1977). Pertanyaan-pertanyaan penelitian yang diajukan kepada responden sewaktu melaksanakan wawancara kemudian dicatat di dalam notes (field note).

Setelah data dikumpulkan menggunakan protokol wawancara tidak berstruktur secara mendalam, pengamatan serta bukti dokumen seperti dikemukakan di atas, aktivitas selanjutnya adalah melakukan analisis dan interpretasi data untuk menjawab pertanyaan penelitian. Analisis data dalam kajian ini terdiri atas tiga tahap yaitu pengurangan data, menyajikan data, menarik kesimpulan dan pembuktian (Miles \& Huberman, 1994).

\section{Pembahasan}

Hasil penelitian dengan menggunakan pendekatan Focus Grup Discussion telah dilakukan pada dua desa terpilih yaitu Desa Aneuk Laot dan Desa Iboih. Kedua desa tersebut dipilih dengan pertimbangan bahwa karakteristik dan eksistensi sebagai destinasi wisata. Desa Aneuk Laot yang terletak dengan pusat Kota Sabang dikenal menawarkan destinasi sejarah dan budaya dan kuliner. Letak desa ini berdekatan dengan Kota Sabang. Sementara itu, Desa Iboih dikenali sebagai destinasi wisata bahari.

FGD dilaksanakan dengan melibatkan kepala desa, Tuha Peuet, tokoh adat dan agama, pemuda dan pelaku wisata lokal. Keterlibatan unsur masyarakat diharapkan dapat memberikan hasil yang representatif.

Hasil penelitian dijelaskan berdasarkan tujuan penelitian yaitu untuk mengetahui bentuk-bentuk kearifan lokal. Berdasarkan hasil kajian diketahui bahwa bentuk 
kearifan lokal dapat dikelompokkan kepada 2 jenis, yaitu bentuk fisik dan bentuk non fisik. Bentuk-bentuk kearifan lokal berbentuk fisik adalah (1) jenis makanan tradisional; (2) permainan tradisional; (3) budaya dan festival. Sedangkan bentuk non-fisik adalah peraturan-peraturan atau Qanun yang berhubungan dengan upaya menjaga dan melestarikan lingkungan yaitu Qanun tentang Adat Laot dan Danau.

\section{Simpulan}

1. Warga masyarakat di Gampong Aneuk Laot dan Gampong Iboih Kecamatan Sukakarya Kota Sabang sepakat untuk mempertahankan nilai-nilai kearifan lokal;

2. Nilai kearifan lokal yang terdapat di lokasi penelitian dapat dikelompokkan kepada (a) nilai kearifan lokal yang ada sejak dahulu dan masih berkembang sampai saat ini; (b) nilai kearifan lokal yang telah hilang dan (c) terdapat potensi nilai kearifan lokal baru sebagai salah satu bentuk daya tarik pariwisata di masa depan;

3. Nilai-nilai kearifan lokal yang terdapat di lokasi penelitian secara umum dapat dikelompokkan kepada tiga unsur yaitu (a) berkaitan dengan aspek ekonomi; (b) berkaitan dengan aspek sosial budaya, dan (c) berkaitan dengan aspek lingkungan;

4. Secara keseluruhan dapat disimpulkan bahwa aspek pemeliharaan sumberdaya alam atau lingkungan merupakan prasyarat utama pengembangan destinasi wisata;

5. Nilai kearifan lokal terutama aspek lingkungan merupakan faktor pendorong kepada aspek ekonomi dan sosial budaya layak dijadikan model kearifan lokal yang dapat menjamin keberlanjutan pembangunan pariwisata di kawasan penelitian. Model kearifan lokal tersebut sudah diformulasikan dalam bentuk peraturan atau Qanun.

\section{Daftar Pustaka}

Andriotis, K., \& Vaughan, R. D. (2003). Urban residents' attitudes towards tourism development: The case of Crete. Journal of Travel Research, 42 (2), 172185.

Ap, J. (1992). Residents' perceptions on tourism impacts. Annals of Tourism Research, 19, 665-690.

Aziz, H. (1995). Understanding attacts on tourists in Egypt. Tourism Management, $16(2), 91-95$.

Azizi Yahaya, Shahrin Hashim, Jamaludin Ramli, Yusof Boon, \& Abdul R. Hamdan. (2006). Menguasai penyelidikan dalam pendidikan: Teori, analisis dan interpretasi data. Kuala Lumpur: PTS Publishing Sdn Bhd.

Badaruddin Mohamed. (2008). Pariwisata lestari. Kuala Lumpur: Dewan Bahasa dan Pustaka.

Baum, T., \& Conlin, M. V. (1997). Brunei Darussalam: Sustainable tourism development within an Islamic cultural ethos. Dalam F. M. Go, \& C. L. Jenkins (Penyunt.), Tourism and economic development in Asia and Australasia. London: Cassell. 
Bird, B. (1989). Langkawi-from Mahsuri to Mahathir: Tourism for whom? Kuala Lumpur: Insan.

Blau, P. (1964). Exchange and power in social life. New York: John Wiley \& Sons.

Brougham, J. E., \& Butler, R. W. (1981). A segmentation analysis of resident attitudes to the social impact of tourism. Annals of Tourism Research, 8 (4), 569-590.

Brown, P. (1996). Catskill culture: The rise and fall of Jewish resort area seen through personal narrative and ethnography. Journal of Contemporary Ethnography, 25 (1), 83-119.

Butler, R. W. (1980). The concept of a tourist area cycle of evolution: Implication for management of resources. Canadian Geografer, 24 (1), 5-12.

Caneday, L., \& Zeiger, J. (1991). The social, economic and environmental costs of tourism to a gaming community as perceived by the residents. Journal of Travel Research, 30 (2), 45-49.

Deery, M., Jago, L., \& Fredline, L. (2012). Rethinking social impacts of tourism research: A new research agenda. Tourism Management, 33 (1), 64-73.

Doxey, G. V. (1975). A causation theory of visitor-resident irritations, methodology and research inferences. In Conference Proceedings: Sixth Annual Conference of Travel Research Association, (hal. 195-198). San Diego.

Fasick, F. A. (1977). Some uses of untranscribed tape recordings in survey research. Public Opinion Quarterly, 41 (4), 549-552.

Faulkner, B., \& Tideswell, C. (1997). A framework for monitoring community impacts of tourism. Journal of Sustainable Tourism, 5 (1), 3-28.

Gursoy, D., \& Rutherford, D. G. (2004). Host attitudes toward tourism: An improved structural model. Annals of Tourism Research, 31 (3), 495-516.

Halcomb, E. J., \& Davidson, P. M. (2006). Is verbatim transcription of interview data always necessary? Applied Nursing Research, 19 (1), 38-42.

Helmi Ali. (2010, Januari 16). Potensi pariwisata Sabang sulit berkembang. Dipetik April 15, 2011, dari http://www.antaranews.com/berita/1263588222/potensi-pariwisatasabang-sulit-berkembang.

Hernandez, S. A., Cohen, J., \& Garcia, H. L. (1996). Residents' attitudes towards an instant resort enclave. Annals of Tourism Research, 23 (4), 755-779.

Ioannides, D. (1995). A flawed implementation of sustainable tourism: The experience of Akamas, Cyprus. Tourism Management, 16 (8), 583-592.

Jennings, G. (2001). Tourism research. Milton QLD: Wiley \& Sons.

Joseph, C. A., \& Kavoori, A. P. (2001). Mediated resistance: Tourism and the host community. Annals of Tourism Research, 28 (4), 998-1009.

Kadir Din. (1989). Islam and tourism: Patterns, issues and options. Annals of Tourism Research, 16, 542-563.

Kalsom Kayat \& Nor Ashikin Moh Nor. (2006). Penglibatan ahli komuniti dalam program pembangunan komuniti: Program homestay di Kedah. Akademika, 67, 77-102. 
Kalsom Kayat. (2002). Power, social exchanges and tourism in Langkawi: Rethinking resident perceptions. International Journal of Tourism Research, 4 (3), 171-191.

Linton, R. (1936). The study of man. New York: Appleton.

Marohaini Yusoff. (2001). Pengutipan dan pengumpulan data perlakuan dan proses menulis karangan dalam bilik darjah. Dalam M. Yusoff (Penyunt.), Penyelidikan kualitatif: Pengalaman kerja lapangan kajian (hal. 87-119). Kuala Lumpur: Penerbit Universiti Malaya.

Mathieson, A., \& Wall, G. (1982). Tourism: Economic, physical and social impacts. Harlow: Longman.

McCool, S. F., \& Martin, S. R. (1994). Community attachment and attitudes toward tourism development. Journal of Travel Research, 32 (3), 29-34.

Miles, M. B., \& Huberman, A. M. (1994). Qualitative data analysis: An expanded sourcebook (2nd ed.). Sage Publication: Thousand Oaks.

Milman, A., \& Pizam, A. (1988). Social impact of tourism on Central Florida. Annals of Tourism Research, 15 (2), 191-204.

Misri A. Muchsin. (2010, Jun 29). Masyarakat jangan takut dampak negatif pariwisata. Dipetik Julai 5, 2011, dari http://www.rakyataceh.com/index.php?open=view\&newsid=17712

Moyle, B., Croy, W. G., \& Weiler, B. (2010). Community perceptions of tourism: Bruny and Magnetic Islands, Australia. Asia Pacific Journal of Tourism Research, 15 (3), 353-366.

Pearce, P. L. (1989). Social impacts of tourism. Dalam The social, cultural and environmental impacts of tourism (hal. 1-39). Sydney: NSW Tourism Commission.

Perdue, R. R., Long, P. T., \& Allen, L. (1990). Resident support for tourism development. Annals of Tourism Research, 17 (4), 586-599.

Pizam, A. (1978). Tourism' impacts: The social costs to the destination community as perceived by its residents. Journal of Travel Research, 16 (4), 8-12.

Preister, K. (1989). The theory and management of tourism impacts. Tourism Recreational Research, 14 (1), 15-22.

Rasid Mail \& Raman Noordin. (2012). Penyelidikan peringkat sarjana: Pendekatan kualitatif sebagai alternatif. Sabah: Penerbit Universiti Malaysia Sabah.

Rothman, R. A. (1978). Residents and transients: Community reaction to seasonal visitors. Journal of Travel Research, 16 (3), 8-13.

Sekaran, U. (2003). Research methods for business: A skill building approach (4ed). Canada: John Wiley \& Sons.

Settina, R. J., \& Richmond, B. O. (1978). U.S. virgin islanders' perceptions of tourism. Journal of Travel Research, 17 (1), 30-31.

Sheldon, P. J., \& Var, T. (1984). Resident attitudes to tourism in North Wales. Tourism Management, 5 (1), 40-47.

Sirakaya, E., Teye, V., \& Sonmez, S. (2002). Understanding residents' support for tourism development in the central region of Ghana. Journal of Travel Research, 41 (1), 57-67. 
The Atjeh Post. (2012, April 28). Warga Ulee Lheue blokir jalan menuju pelabuhan. Dipetik Jun 2, 2012, dari http://atjehpost.com/read/2012/04/28/7682/15/5/Warga-Ulee-LheueBlokir-Jalan-Menuju Pelabuhan

The Globe Journal. (2012, Mei 13). Masyarakat dan WH bakar pondok wisata Lhoknga. Dipetik Jun 25, 2012, dari http://theglobejournal.com/sosial/masyarakat-dan-wh-bakar-pondokwisata-lhoknga/index.php

The Globe Journal. (2011, Disember 30). Sekjen HUDA tolak pembangunan Best Western hotel. Dipetik April 23, 2012, dari http://theglobejournal.com/sosok/sekjen--huda-tolak-pembangunan-bestwestern-hotel/index.php

Thomason, P., Crompton, J. L., \& Kamp, B. D. (1979). A study of the attitudes of impacted groups within a host community toward prolonged stay tourist visitors. Journal of Travel Research, 17 (3), 2-6.

Timothy, D. J. (1999). Participatory planning: A view of tourism in Indonesia. Annals of Tourism Research, 26 (2), 371-391.

Totok Yulianto. (2008, Disember 2). Sharia deters tourists from Aceh. Dipetik Julai 9, 2010, dari The Jakarta Post: http://www.thejakartapost.com/news/2008/12/02/sharia-deters-touristsaceh.html

Tsundoda, T., \& Mendlinger, S. (2009). Economic and social impact of tourism on a small town: Peterborough New Hampshire. Journal of Service Science and Management, 2 (2), 61-70.

Var, T., Kendall, K. W., \& Tarakcioglu, E. (1985). Resident attitudes towards tourists in a Turkish resort town. Annals of Tourism Research, 12 (4), 652658.

Veal, A. J. (1997). Research methods for leisure and tourism: A practical guide (Second ed.). Essex: Pearson Education Limited.

Zamani-Farahani, H., \& Henderson, J. C. (2010). Islamic tourism and managing tourism development in Islamic societies: The case of Iran and Saudi Arabia. International Journal of Tourism Research, 12, 79-89.

Zamani-Farahani, H., \& Musa, G. (2012). The relationship between Islamic religiosity and residents' perceptions of the socio-cultural impacts of tourism in Iran: Case studies of Sare'in and Masooleh. Tourism Management, 33 (4), 802-814. 